\title{
PANCASILA SEBAGAI "SCREENING BOARD” DALAM MEMBANGUN HUKUM DI TENGAH ARUS GLOBALISASI DUNIA YANG MULTIDIMENSIONAL
}

\author{
Kuat Puji Prayitno \\ Fakultas Hukum Universitas Jenderal Soedirman Purwokerto \\ E-mail: kuatunsoed@yahoo.com
}

\begin{abstract}
Globalization implies a deep and occurs in all aspects of life. Faced with the problems of globalization, the development of national law must be put Pancasila as the "margin of appreciation" or even "screening board" which will have implications in the formation of legal theory and practice of law in Indonesia. The challenge is how a nation capable of protecting its national interests (national interest) in the middle of the global atmosphere and make the local values as "screening board" in the institutionalization of universal values. Five Principles for the Indonesian nation is the core philosophy, which is a local genius and local wisdom of Indonesia. Therefore Pancasila as a source of value to the legal system. Thus, Pancasila is also an ideal law (rechts idee) is understood as the legal construction of thought that leads to the desired goal.
\end{abstract}

Keywords: Pancasila, grundnorm, globalization

\begin{abstract}
Abstrak
Globalisasi mengandung makna yang dalam dan terjadi di segala aspek kehidupan. Dihadapkan pada persoalan globalisasi, maka pembangunan hukum nasional harus meletakkan Pancasila sebagai "margin of appreciation" atau bahkan "screening board" yang akan berimplikasi dalam pembentukan teori hukum dan praktik hukum di Indonesia. Tantangannya adalah bagaimana suatu bangsa mampu melindungi kepentingan nasionalnya (national interest) di tengah suasana global dan menjadikan nilai-nilai lokal sebagai "screening board" dalam pelembagaan nilai-nilai universal. Pancasila bagi bangsa Indonesia merupakan core philosophy, sehingga merupakan suatu local genius dan local wisdom bangsa Indonesia. Oleh karena itu Pancasila merupa-kan sumber nilai bagi adanya sistem hukum. Dengan demikian Pancasila juga merupakan cita hukum (rechts idee) yang dipahami sebagai konstruksi pikir yang mengarahkan hukum pada cita-cita yang diinginkan.
\end{abstract}

Kata kunci: Pancasila, grundnorm, globalisasi

Pendahuluan

Globalisasi dipahami sebagai suatu tatanan masyarakat baru yang didalamnya tidak lagi membicarakan hal-hal yang sifatnya lokal. Transformasi global telah merambah ke seluruh dunia, yang mana tidak ada lagi batas-batas yang jelas dalam suatu negara, budaya, transformasi, ekonomi, hukum dan bahkan perilaku masyarakat. Dinamika global ini diwarnai oleh pemikiran ekonomi dunia dengan kekuatan pasar bebas yang mengendalikannya. Dengan globalisasi, perkembangan dan pengaruhnya muncul pula pandangan-pandangan baik yang pro maupun kontra. Landasan-landasan kultural, ekonomi, sosial, politik dan lainnya menjadi dasar pemikiran kedua belah pihak.

Pada sisi lain banyak negara-negara berkembang tidak mampu bersaing yang memang diciptakan oleh negara-negara maju, dan pada gilirannya globalisasi justru menghambat pemerintah negara-negara berkembang menjalan-kan kebijakan apabila tidak sesuai dengan norma yang berlaku secara global. Munculah pandangan pengkategorian negara-negara dalam beberapa posisi yang menunjukkan kekuatan negara tersebut dalam percaturan dunia. Pembagian posisi tersebut adalah dominance (Amerika Serikat, Eropa Barat, Australia, dan Jepang); strong (New Industries Countries yaitu: Singapura, Korea, Hongkong); neutral (Cina, Malaysia, Thailand); weak (salah satunya Indo- 
nesia; dan Unknown/Unnotice (negara-negara terbelakang). ${ }^{1}$

Globalisasi menurut teori-teori sesungguhnya mengandung fenomena sebagai berikut. Pertama, homogenisasi. Fenomena yang disebabkan oleh kemajuan teknologi komunikasi sehingga terjadi homogenisasi masyarakat global. Nilai-nilai budaya setempat akan diuji dan terdistorsi oleh kehadiran nilai-nilai global. Kedua, ketergantungan. Negara-negara maju sebagai pelopor globalisasi menciptakan ketergantungan negara-negara di dunia, sehingga banyak negara berkembang tidak dapat berbuat banyak. Ketiga, keterbukaan dan integrasi. Kemajuan di bidang teknologi komunikasi dan informasi menjadi dunia semakin terbuka dan terintegrasi. Batas-batas wilayah geografi suatu negara tidak begitu penting lagi. ${ }^{2}$

Globalisasi mengandung makna yang dalam dan terjadi di segala aspek kehidupan seperti ekonomi, sosial budaya, poilitik, ilmu pengetahuan dan teknologi, hukum dan sebagainya. Menurut Muladi globalisasi yang ditandai dengan revolusi informasi menuntut nilainilai dan norma-norma baru dalam kehidupan skala nasional maupun internasional. ${ }^{3}$

Proses globalisasi akan terus berlangsung tanpa ada kendali dan siapapun tidak akan mampu menghentikannya karena globalisasi adalah sebuah idiologi yang tampaknya sudah disiapkan oleh negara-negara industri maju agar semua negara di dunia terinkorporasi ke dalam masyarakat dunia yang tunggal, masyarakat global dengan kapitalisme dan liberalisme sebagai panglimanya. ${ }^{4}$

Strategi pembangunan hukum nasional diletakkan pada nilai dasar pembangunan hukum yaitu Pancasila dan UUD 1945. Konsistensi

Miyasto, 2007, Bahan Kuliah/Matrikulasi Transformasi Global (Ekonomi), PDIH UNDIP, Semarang

2 Adolf, Huala dam Agus Irianto, 2007, Globalisasi dan Dampaknya Terhadap Sistem Regulasi Bidang Investasi Dalam Pelaksanaan Otonomi Daerah, Yogyakarta: Genta Press, hlm. 347.

3 Muladi, tanpa tahun, Menjamin Kepastian, Ketertiban, Penegakkan dan Perlindungan Hukum Dalam Era Globalisasi, Makalah, hlm. 4.

4 Joni Emirzon, 2007, "Strategi Hukum Dalam Pembangunan Hukum Ekonomi Indonesia di Era Globalisasi", Jurnal Hukum Progresif, PDIH UNDIP, Vol. 2 No. 2 hlm. 120. pemilkiran ini harus ditempuh karena Pancasila bagi bangsa Indonesia adalah sebagai dasar filosofis, pandangan hidup dan dasar negara yang melandasi pembangunan hukum.

Dihadapkan pada persoalan globalisasi, maka pembangunan hukum nasional harus meletakkan Pancasila sebagai "margin of appreciation" atau bahkan "screening board" yang akan berimplikasi dalam pembentukan teori hukum dan praktik hukum di Indonesia.

Terjadi apa yang disebut sebagai kondisio "open system" mengingat besarnya pengaruh lingkungan terhadap orde politik, ekonomi, sosial dan hukum. Oleh karena itu yang menjadi tantangan adalah bagaimana suatu bangsa mampu melindungi kepentingan nasionalnya (national interest) di tengah suasana global dan menjadikan nilai-nilai lokal sebagai "screening board" dalam pelembagaan nilai-nilai universal.

Pancasila bagi bangsa Indonesia merupakan core philosophy, sehingga merupakan suatu local genius dan local wisdom bangsa Indonesia. ${ }^{5}$ Kedudukan Pancasila bagi bangsa Indonesia dengan demikian dapat dikatakan merupakan Grundnorm atau basic norm, yang menurut Hans Kelsen "basic norm's as the source of validity and as the source of unity of legal systems". ${ }^{6}$ Oleh karena itu Pancasila merupakan sumber nilai bagi adanya sistem hukum. Dengan demikian Pancasila juga merupakan cita hukum (rechts idee) yang dipahami sebagai

5 Kaelan, 2006, Pancasila Sebagai Dasar Orientasi Pengembangan Ilmu Hukum, Jakarta, hlm. 6. Bandingkan persoalan kearifan lokal ini atau local genius ini dengan tulisannya FX. Adji Samekto, "Kajian Studi Hukum Kritis: Implikasi Yuridis "Ketidak-Ilmiahan" Pengetahuan Tradisional dalam Pengelolaan Keanekaragaman Hayati”, Jurnal Hukum Pro Justitia Tahun XIII No. 1 Januari 2005 FH Unpar Bandung, hlm. 1-7. Lihat dan bandingkan pula dengan tulisan Imam Koeswahyono, "Mempertemukan dan Membumikan Pandangan Teoritik dan Praktik: Suatu Upaya Pembaruan Hukum, Jurnal Hukum Jentera Edisi 10 Tahun III Oktober 2005, hlm. 114-116.

6 Kaelan, op.cit. Lihat juga pemikiran Hans Kelsen ini dalam Suadamara Ananda, "Tentang Kaidah", Jurnal Hukum Pro Justitia Vol 26 No. 1 Januari 2008 FH Unpar Bandung, hlm. 68-78. 
konstruksi pikir yang mengarahkan hukum pada cita-cita yang diinginkan. ${ }^{7}$

Permasalahan yang hendak dibahas dalam artikel ini adalah mengenai posisi Pancasila sebagai pandangan hidup bangsa (way of life) atau (Weltanschauung), dan sebagai dasar negara (Staatsfundamentalnoorm) dalam pembangunan hukum di tengah arus Globalisasi yang multidimensional.

\section{Pembahasan}

Pengaruh Globalisasi Dunia dan Tantangan Pembangunan Hukum Nasional

Globalisasi sudah merupakan keniscayaan sebagai konsekuensi majunya teknologi. Dengan globalisasi terjadi peningkatan makna dan peristiwa yang terjadi di seluruh dunia yang menyebar dengan cepat untuk membentuk suatu dunia yang tunggal, terintegrasi secara ekonomi, sosial, budaya, teknologi, bisnis dan pengaruh lainnya yang menembus batas dan sekat tradisional seperti bangsabangsa, kebudayaan nasional, ruang, waktu. ${ }^{8}$ Definisi Globalisasi itu sendiri sebagai penyebaran kebiasaan-kebiasaan yang mendunia, ekspansi hubungan yang melintasi batas negara/benua, organisasi dari kehidupan sosial pada skala global, dan pertumbuhan dari se-buah kesadaran global bersama. ${ }^{9}$

Bangsa yang cerdas dalam era globalisasi, bukan bangsa yang terus mengeluh, menyerah, dan marah, tetapi bangsa yang secara cerdas mampu mengalirkan sumber-sumber kesejahteraan yang tersedia di arena global itu. Apakah teknologi, apakah modal, apakah informasi, yang akhirnya kita gunakan dengan baik untuk meningkatkan kesejahteraan kita, meningkatkan kepentingan kita. Sering dikatakan, don't be a loser, jangan mau jadi orang yang kalah. Mari kita menjadi pemenang, to be a winner dalam globalisasi ini.

Sholehuddin, 2004, Sistem Sanksi Dalam Hukum Pidana, Ide Dasar Double Track System \& Implementasinya, Jakarta: Raja Grafindo Persada, hlm. 23.

8 Barbara Parker dalam Ade Maman Suherman, 2005, Aspek Hukum Dalam Ekonomi Global, Ciawi Bogor: Ghalia Indonesia, hlm. 15.

9 Frank Lechner dalam George Ritzer, 2006, The Globalization of Nothing, Yogyakarta: Universitas Atmajaya, hlm. 96.
Kita mesti membangun Indonesia baru, remaking Indonesia, rebirth of a nation. Oleh karena itu, dalam konteks itu, muncul sejumlah kecenderungan. Secara sosiologis, kita mengetahui satu kerawanan dalam masa transisi yaitu; nilai dan tatanan lama telah ditinggalkan, sementara nilai dan tatanan baru belum terwujud. Bahkan barangkali, kita belum membangun konsensus baru bagi terbangunnya nilai dan tatanan dalam reformasi ini, tanpa meninggalkan fundamental consensus yang telah diletakkan oleh para Pendiri Republik.

Transisi yang kita lakukan ini, justru berada dalam lingkungan global yang juga terus berubah. Dunia yang menghadirkan gerak globalisasi dan universalisasi yang luar biasa dampaknya bagi semua bangsa di dunia, termasuk negara kita. Kita mengalami sejumlah tonggak sejarah. Tonggak pertama, 1945. Kita melakukan perubahan dan pembaharuan dalam dunia yang ditandai era dekolonisasi. Tonggak kedua, 1966, kita menata kembali kehidupan bernegara kita dalam suasana era perang dingin. Sekarang ini, 1998 ke depan, kita ingin mengkonstruksikan kembali negara kita dalam era globalisasi dan demokratisasi sejagad.

Pandangan bahwa nation state tidak relevan lagi di dalam globalisasi, dalam dunia yang borderless. Paham borderless world ini tentu banyak ditentang oleh negara-negara yang lemah, namun didukung oleh negara-negara kuat yang memelihara hegemonisme dan predatorisme. ${ }^{10}$ Pelaku dan korban "pembodohan sosial" ini tak terkecuali pula sebagian dari kaum intelektual kita, yang sama-sama termakan oleh pola pikir atau mindset asing yang

10 Untuk paham nasionalisme dan dinamikanya, lihat tulisan Leah Greenfeld, 2001, The Spirit of Capitalism: Nationalism and Economic Growth, Cambridge, Mass.: Harvard University Press; tulisan Ian S. Lustick, "The Riddle of Nationalism: The Dialectic of Religion and Nationalism in the Middle East", Logos, Vol. One Issue Three, Summer 2002; tulisan Benedict Anderson, 1983, Imagined Communities: Reflection on the Origin and Spread of Nationalism, Wonder: Verso. Mengenai hegemonisme dan predatorisme, lihat tulisan James Petras dan Henry Veltmeyer, 2001, Globalization Unmasked: Imperialism in the 20 th Century. London: Zed Books,. 
dengan sengaja ingin menempatkan bangsa kita pada posisi subordinasi. ${ }^{11}$

Strategi pembangunan hukum nasional di tengah arus globalisasi yang multi dimensional dengan demikian harus tetap terkendali dengan Pancasila sebagai "Margin of Appreciation dan Screening Board". Pokok-pokok pikiran yang harus menjadi acuan pembangunan hukum adalah sebagai berikut. Pertama, hukum itu berwatak mengayomi/melindungi segenap bangsa dan tumpah darah Indonesia, berdasarkan persatuan dalam rangka mewujudkan keadilan sosial bagi seluruh rakyat Indonesia; kedua, hukum harus mampu mewujudkan keadilan sosial bagi seluruh rakyat Indonesia; ketiga, hukum berasal dari rakyat dan mempunyai sifat kerakyatan atau dengan kata lain adanya prinsip kedaulatan rakyat; dan keempat, hukum berdasarkan nilai Ketuhanan Yang Maha Esa, yang memberikan dasar pengaturan terhadap adanya hukum-hukum Tuhan, di samping memperhatikan nilai-nilai kemanusiaan, nilai-nilai moral, dan budi pekerti yang luhur.

Muladi berpendapat bahwa Pancasila pada dasarnya merupakan kristalisasi pelbagai "common denominators" yang merupakan jawaban atas akar permasalahan (root cause), merupakan sistem nilai luhur bangsa Indonesia

11 Kaum intelektual kita tersebut tidak sadar bahwa dalam posisi subordinasi itu, kita tidak bisa memusatkan diri untuk menolong bangsa kita sendiri dari keterpurukan sosial-ekonomi yang sedang dialaminya. Bahkan sebagian di antara kaum intelektual kita itu cenderung menjadi "corong" bagi intrusi dalam rangka strategi kekuatan asing yang ingin menguasai (overheersen) tanah air dan bangsa kita sebagai kecenderungan (instinct) hegemonisme dan predatorisme, dari segi ekonomi, sosial dan budaya, melalui cara-cara yang canggih dan seringkali sangat terselubung. Dengan kata lain, adalah suatu absurditas bahwa mindset rendah diri (minder) terbentuk di kalangan sejumlah kaum intelektual kita, yang mewajarkan globalisasi sebagai proses subordinasi nasional, dan yang mewajarkan gagasan bahwa tidaklah penting bagi kita untuk menjaga kepentingan nasional, kedaulatan nasional dan integritas teritorial, pada saat mereka menerima doktrin superordinasi tentang the borderless world seperti tersebut di atas. Tidaklah berarti bahwa nasionalisme Indonesia harus mengabaikan tanggung jawab global, namun sebaliknya, kita harus menghormati tanggung jawab global dengan tetap mengutamakan dan membela kepentingan nasional kita sendiri. Lihat tulisan James Retras dan Henny Veltmeyer, op. cit., dan tulisan J.W. Smith, 2000, Economic Democracy: The Political Struggle of the Twenty-First Century, New York: M.E. Sharpe. yang sudah ultimate dan definitif, sekaligus merupakan refleksi dari reaksi persoalan-persoalan bangsa secara riil, ${ }^{12}$ termasuk ketika menghadapi fenomen globalisasi dunia.

\section{Reformasi Hukum Sebagai Upaya Menata Hukum Nasional}

Hakekat reformasi adalah "pembaharuan" dan juga "back-to-basics", dalam arti meluruskan yang keliru dan keluar jalur. Kemajuan peradaban tidak terlepas dari proses pembelajaran makna sejarah sebagai acuan untuk membangun masa depan.

Reformasi (reform movement) yang bergulir di awal tahun 1988, harus diartikan sebagai langkah strategis bangsa dan rakyat Indonesia untuk mengaktualisasikan kembali secara sistematis nilai-nilai dasar (core values) atau indexs (indices) dari demokrasi. Di era reformasi justru nilai-nilai dasar inilah yang diaktualisasikan dengan pendekatan "accelerated evolution". ${ }^{13}$

Menurut Muladi ${ }^{14}$ "Law Reform" harus mengandung makna-makna sebagai proses dekolonisasi hukum; proses demokratisasi hukum; proses harmonisasi hukum terhadap instrumeninstrumen internasional; proses penggunaan hukum sebagai sarana perobahan peradaban; proses konsolidasi hukum untuk menata kembali hukum dalam kerangka asas-asas hukum yang utuh; dan proses untuk menjadikan ideologi Pancasila sebagai "Margin of Appreciation" dalam reformasi hukum.

Oleh karena itu permasalahan pokok politik pembangunan hukum nasional antara lain sebagai berikut. Pertama, memperbarui atau mengganti peraturan hukum dari masa kolonial yang masih berlaku; dan kedua, menciptakan hukum baru yang secara utuh bersumber pada Pancasila dan UUD 1945 sesuai dengan tuntutan dan perkembangan masyarakat pada

12 Muladi, 2006, Pancasila Sebagai Dasar Pengembangan Ilmu Hukum Indonesia, hlm. 4.

13 Muladi, 2005, "Menggali Kembali Pancasila Sebagai Dasar Pengembangan Ilmu Hukum Indonesia", Jurnal Hukum Progresif, Volume I/Nomor 1/April 2005.

14 Muladi, 2007, Reformasi Hukum Dalam Kerangka Pembangunan Sistem Hukum Nasional, Jakarta: LEMHANNAS, hlm. 3. 
tingkat lokal, nasional, regional, dan internasional dalam era globalisasi. ${ }^{15}$

Proses dekolonisasi hukum secara mendasar tidak hanya berarti usaha mengganti perundang-undangan warisasn kolonial, tetapi juga merubah paradigma pendidikan hukum di Indonesia. Pendidikan hukum yang menggunakan tradisi Civil Law dari Eropa Kontinental yang cenderung mengajarkan positivisasi hukum yang memberlakukan hukum sebagai kaidah-kaidah positif, bersifat yuridis normatif disertai penalaran formal deduktif. Pendekatan semacam ini sangat bermanfaat untuk menciptakan pembenaran (justification) atau legitimasi, bukan kebenaran (truth) yang bersifat empiris. ${ }^{16}$ Dengan sistem pendidikan hukum semacam ini hukum cenderung sebagai alat kekuasaan semata-mata (Law as the command of the sovereign).

Mengapa kita harus bicara kembali tentang Pancasila? Ini pertanyaan fundamental yang mesti kita jawab bersama. Kita merasakan, di tengah-tengah gerak reformasi dan demokratisasi yang berlangsung di negeri kita, terkadang kita kurang berani, kita menahan diri, untuk mengucapkan kata-kata semacam Pancasila, Undang-Undang Dasar 1945, NKRI, Bhinneka Tunggal Ika, Wawasan Kebangsaan, Stabilitas, Pembangunan, Kemajemukan dan lain-lain. Oleh karena bisa-bisa dianggap tidak sejalan dengan gerak reformasi dan demokratisasi. Bisa-bisa dianggap tidak reformis

Kita ingin meletakkan Pancasila sebagai rujukan, sumber inspirasi dan jendela solusi untuk menjawab tantangan nasional menuju Indonesia yang kita cita-citakan bersama, sesungguhnya kita bersyukur kepada Allah SWT, karena kita telah meletakkan dan menggunakan

15 Satya Arinanto, "Politik Pembangunan Hukum Nasional Dalam Era Pasca Reformasi", Jurnal Konstitusi, Volume 3 Nomor 3, 2006, hlm. 92.

16 Lihat dan baca persoalan hukum yang normatif ini pada FX. Adji Samekto, "Kajian Hukum: Antara Studi Normatif dan Keilmuan", Jurnal Hukum Progresif Vol 2 No. 2 Oktober 2005 PDIH Undip Semarang, hlm. 55-68; Paulus Hadisuprapto, "Ilmu Hukum dan Pendekatannya”, Jurnal Hukum Progresif Vol 2 No. 2 Oktober 2005 PDIH Undip Semarang, hlm. 35-54. Lihat juga Muchyar Yara, "Teori Hukum (Suatu Tinjauan Singkat tentang Posisi, Sejarah Perkembangan dan Ruang Lingkupnya", Jurnal Hukum dan Pembangunan No. 1-3 Tahun XXVIII Januari-Juni 1998 FH Ul Jakarta, hlm. 1-20.
Pancasila dengan benar. Sebab Pancasila adalah falsafah, dasar negara dan ideologi terbuka. Open ideology, living ideology. Bukan dogma yang statis dan menakutkan. Pancasila kita letakkan secara terhormat. Sebagaimana saya katakan, menjadi sumber pencerahan, menjadi sumber inspirasi, dan sekaligus sumber solusi atas masalah-masalah yang hendak kita pecahkan. Kita ingin menata kembali kerangka kehidupan bernegara berdasarkan Pancasila.

Terkait dengan transformasi global, kita bukan untuk sekedar mengikuti arus globalisasi secara otomatis, akan tetapi justru untuk dapat memilih secara sadar kaedah-kaedah asing, internasional, atau transnasional yang mana, yang baik atau boleh kita terima dan yang mana seyogyanya tidak kita terima ke dalam sistem hukum nasional kita, atau bahkan harus kita tolak demi pelestarian jati diri dan kepribadian bangsa Indonesia. ${ }^{17}$

Reformasi, hakikatnya adalah perubahan dan kesinambungan, continuity and change. Oleh karena itu, kalau kita mengangkat kembali hari ini, tentang hakikat dan makna Pancasila, mestilah kita letakan dalam konteks makna sejati dari reformasi yang tengah kita lakukan dewasa in. Hal-hal yang masih baik, tepat dan relevan, dan justru merupakan nilai, jati diri dan konsensus-konsensus dasar, harus terus kita lanjutkan. Sementara, sesuatu yang tidak sesuai lagi, yang tidak tepat lagi pada jamannya, mesti bersama-sama kita lakukan perubahan dan pembaharuan.

Oleh karena itu, pada saat generasi penerus dan cendekiawan kita masa kini belum mampu menyusun suatu pedoman acuan lain yang dianggap dapat mengungguli Pancasila dan Undang-Undang Dasar 1945 untuk menjaga persatuan bangsa, mensejahterakan rakyat Indonesia dan menjaga keutuhan tanah air kita, maka pada saat ini, niat untuk menghapus Pancasila itulah yang harus ditanggalkan dari mindset kita. Sebaliknya, distorsi terhadap mindset perlu diluruskan dengan cara memahami Pancasila yang sebenarnya. Hal ini merupakan suatu

17 Sunaryati Hartono, 1991, Pembinaan Hukum Nasional Dalam Suasanan Globalisasi Masyarakat Dunia, Pidato Pengukuhan Guru Besar, UNPAD, Bandung 
tindakan yang dilandasi oleh suatu urgensi untuk menghindarkan bangsa kita dari ketidakadilan yang menyebabkan kekacauan, ketidakrukunan, makin luasnya disintegrasi sosial, serta koyaknya keutuhan negara. ${ }^{18}$

Sunaryati Hartono menyebutkan ada lima belas komponen yang diperlukan dalam merumuskan perencanaan dan implementasi pembangunan hukum nasional, satu diantaranya adalah filsafat dan asas-asas hukum nasional yang tidak lain adalah Pancasila. Kelimabelas komponen itu adalah sebagai berikut: filsafat dan asas-asas hukum nasional; wawasan dan pendekatan pembinaan hukum nasional; kaidah-kaidah hukum (termasuk yurisprudensi dan hukum kebiasaan); pranata-pranata hukum; lembaga-lembaga hukum; kesadaran hukum nasional; sikap dan perilaku hukum; proses dan prosedur, cara dan mekanisme hukum; monitoring, analisis dan evaluasi, pengkajian dan penelitian hukum; sistem pendididkan hukum (formal, non-formal dan informal); ilmu hukum nasional; profesi hukum, para penegak hukum dan pejabat/petugas pelayanan hukum; penyedia data, bahan, kepustakaan dan informasi hukum; sarana dan prasarana fisik dan non fisik; dan rencana-rencana pembangunan hukum. ${ }^{19}$

Persoalan pembangunan hukum yang menggunakan Pancasila sebagai batu pijakannya (a corner stone) atau kaidah penuntun (guiding principle) di arus globalisasi dunia sekaligus dapat berfungsi sebagai kaidah evaluasi. Kelima butir Pancasila itu merupakan refleksi buah pikiran yang telah secara tulus ikhlas dipersiapkan secara serius dan mendalam oleh para pendiri negara kita menjelang Proklamasi Kemerdekaan Indonesia tanggal 17 Agustus 1945, kemudian dimatangkan (dalam wadah Badan Penyelidik Usaha-usaha Persiapan Kemerdekaan Indonesia, disingkat BPUPKI) untuk menjadi pedoman berperilaku nasional

18 Susilo Bambang Yudoyono, 2006, Menata Kembali Kehidupan Bernegara Berdasarkan Pancasila, Pidato Presiden Dalam Rangka Memperingati Hari Lahir Pancasila, 1 Juni 2006

19 Sunaryati Hartono, dalam B. Arief Sidharta, 2000, Refleksi Tentang Struktur Ilmu Hukum Sebuah Penelitian Tentang Fondasi Kefilsafatan dan Sifat Keilmuan Ilmu Hukum Sebagai Landasan Pembangunan Ilmu Hukum Nasional Indonesia, Mandar Maju, Bandung dalam kehidupan berbangsa dan bernegara. Dengan dasar negara itu maka bangsa ini memiliki pegangan dan rujukan, tidak "ela-elo" (Sastro Gending di zaman Sultan Agung yang menggambarkan porak-porandanya bangsa ini, seakan kehilangan pegangan, jati diri, harga diri dan percaya diri). ${ }^{20}$

\section{Penegakkan Hukum sebagai "Searching The Truth and Justice"}

Secara teoritis maupun praktis hukum sebagai sebuah disiplin hendaknya memiliki model analisis dan mampu menyelesaikan ragam persoalan. Satu hal yang telah mapan dan dirasakan dirasakan sangat mengganggu adalah terlalu sempitnya lingkup batasan hukum yang dikemukakan para teoritisi konvensional. Hukum digambarkan sebagai suatu wilayah yang steril dan tertutup, terkerangkeng dalam wilayah logika saja. Akibatnya keterbatasan metodologi tidak dapat dihindari, hukum mengalami kesulitan untuk melakukan terobosan analisis bahkan kesulitan membentuk disain analisisnya sendiri.

Analisis hukum berakhir pada apa yang disebut sebagai dominasi wilayah yang sempit, yaitu klaim bahwa analisis yuridis adalah wilayah aturan, kaidah dan sanksi. Kekuatan hukum hanya nampak pada prosedur dan formalisme. Hegemoni pandangan sempit ini sangat kuat dan tidak ayal teori hukum, metodologi, pendidikan hukum dan praktik hukum merupakan bentuk nyata dari pandangan ini. Suatu analisis hanya akan dianggap analisis hukum apabila analisis itu sangat logis, berada dalam logika

20 Lihat tulisan S.E. Swasono yang menggambarkan kekacauan dan porak-porandanya bangsa ini dengan mengacu kepada isi senandung Sastro Gending di zaman Sultan Agung Mataram, "Ela-elo ...", yang pada dasarnya melukiskan kekacauan jati diri, harga diri dan percaya diri, yang berlanjut terus sehingga sekedar menjadi koelie, memperoleh "cap" het zachte volk ter aarde, een koelie onder de volkeren (bangsa paling lemah di muka bumi, kuli dari segala bangsa), dan bangsa inlander (pribumi yang mengandung konotasi klas bawah yang terbelakang) dan kehilangan semangat juang dalam membela harga dirinya. S.E. Swasono, "Pluralisme, Mutualisme dan Semangat Bersatu: Mempertanyakan Jatidiri Bangsa", makalah diajukan pada Dies Natalis ke-57 Fakultas IImu Budaya UGM, Yogyakarta 25 Februari 2003). 
sistem hukum dan menggunakan term yang dikenal dalam keilmuan hukum.

Hukum menurut pandangan yang steril ini, secara filososfis atau metodologis harus terpisah dari ilmu-ilmu lain. Meski tidak langsung gagasan ini adalah contoh dari hegemoni (dominasi) filsafat Cartesian-Newtonian, suatu disiplin selalu haris bersifat jelas dan terpilahpilah (distincy and cleary). ${ }^{21}$

Mewarisi pemikiran abad ke sembilan belas yang bersifat dikotomis, memisahkan manusia berhadap-hadapan dengan alam sebagai obyek sains dan kemudian menggarapnya dengan rasio dan logika, maka hukum dihadapi oleh para penstudi sebagai entitas terpisah, yang harus disoroti, diiris-iris (dissection), dengan bantuan logika. Sama dengan apa yang terjadi pada fisika, maka hasilnya adalah potret hukum yang tidak utuh, melainkan mengalami atomisasi dalam bentuk bangunan dan sistem peraturan.

Kritik terhadap cara-cara orang mempelajari hukum yang klasik atau tradisional itu bermunculan antara lain dari Satjipto Rahardjo yang mengatakan bahwa Ilmu hukum yang demikian itu dikenal sebagai "rechtsdogmatiek" atau "analytical jurisprudence". Dengan terpaku pada hukum perundang-undangan, maka studi hukum menjadi semakin terasing (alienated) dari realitas dalam masyarakat. Ilmu hukum semakin menjadi ilmu pengetahuan tentang skeleton hukum daripada yang utuh, tidak hanya kerangka, tetapi juga "darah daging hukum itu". ${ }^{22}$

Studi yang dilakukan oleh Nonet \& Selznick tahun 1978, menunjukan bahwa ilmu hukum klasik atau tradisional, yang banyak bertumpu pada skema hukum, prosedur hukum, logika hukum, kurang berhasil menyelesaikan berbagai persoalan masyarakat. Kenyataan yang terjadi adalah menyelesaikan persoalan masyarakat lebih mengedepankan logika hukum dan mengabaikan logika sosial. Problema sosial

21 Otje Salman dan Anton F. Susanto, 2004, Teori Hukum (Mengingat, Mengumpulkan dan Membuka Kembali), Bandung: Refika Aditama, hlm. 12-13

22 Satjipto Rahardjo, 2006, Pancasila, Hukum dan Ilmu Hukum, Makalah, UGM-Universitas Pancasila, Jakarta, hlm.14-15. bersifat variatif dan kompleks sehingga tidak dapat diselesaikan melalui cara-cara yang finite dan kaku. Maka disarankan digunakannya "social science strategy" atau "developmental model". 23

Alan Hunt dalam studinya mengemukakan bahwa Memahami hukum tidak bisa dipisahkan dari entitas masyarakatnya. IImu hukum hendaknya lebih ditarik kearah sosial (the social movement in (aw) agar mampu melayani penyelesian dengan lebih memuaskan. ${ }^{24}$

Gugatan terhadap cara-cara orang mempelajari hukum yang bersifat klasik juga muncul dari Brian Z. Tamanaha dengan ilmunya "A General Jurisprudence of Law and Society" yang membahas keterkaitan erat antara hukum dan masyarakatnya mengemukakan bahwa hukum merefleksikan atau cermin/mencerminkan masyarakatnya (law is reflection - a 'mirror'- of society). ${ }^{25}$

Gugatan yang tidak kalah pentingnya adalah dalam rangka mendekatkan pada realitas perubahan sosial yang terjadi rupanya hukum sebagai skema yang rampung (finite schema) tidak mampu untuk berkompetisi dengan perubahan dalam masyarakat.

Berdasarkan hal tersebut, gagasan-gagasan tentang hukum khususnya pandangan konvensional/sempit/dan steril wajib mengalami perumusan ulang. Selain mentradisikan hukum sebagai legal science, ilmu hukum ditempatkan sejajar dengan garis depan sains (tidak mengisolasi diri dari perkembangan ilmu pengetahuan pada umumnya). Hukum juga harus ditata secara holistik yang tidak melihat hukum sebagai skema-skema artifisial yang finite, melainkan sebagai bangunan yang tertanam dan berakar pada masyarakatnya. ${ }^{26}$

Ibid, hlm. 17

24 Ibid, hlm. 16

25 Tamanaha, Brian Z., 2006, A General Jurisprudence Of Law And Society, New York: Oxford University Press, hlm. 1.

26 Lihat mengenai pendekatan holistik terhadap hukum pada Satjipto Rahardjo, "Pendekatan Holistik terhadap Hukum", Jurnal Hukum Progresif Vol. 1 No. 2 Oktober 2005, PDIH Undip Semarang, hlm. 1-4; dan Metode Holistik, Suatu Revolusi Epistemologis", Jurnal Hukum Progresif Vol. 2 No. 2 Oktober 2006, PDIH Undip Semarang, hlm. 1-34. 
Sebagai wilayah yang terbuka hukum menjadi domain bagi telaah disiplin lain (multi). Pengajaran hukum, paradigma hukum mengalami perombakan karena secara filosofis dan metodologis hukum mengalami perubahan dari tatanan yang steril menjadi tatanan multi (pluralis) kultural. Satjipto Rahardjo katakana bahwa ilmu hukum berkembang dari yang terkotak-kotak menuju holistik. ${ }^{27}$ Model ini menawarkan semacam integrasi menuju kesatuan konseptual dalam ilmu pengetahuan.

Consilience adalah suatu lompatan dalam hal pengetahuan dengan jalan mempertalikan fakta diseluruh disiplin ilmu, guna menciptakan suatu dasar penalaran atau alasan yang sama untuk memberikan keterangan-keterangan. Bahwa ilmu hukum tidak bisa dibicarakan terlepas dari apa yang terjadi dalam dunia ilmu pengetahuan pada umumnya

Pembalikan paradigmatik (revolusioner) dalam dunia pendidikan hukum perlu dilakuan. Satjipto Rahardjo dalam setiap perkuliahan di Program Doktor IImu Hukum UNDIP selalu mengingatkan kepada muridnya akan kedudukan hukum sebagai obyek ilmu dan mengokohkan eksistensi tentang program keilmuan. Para ilmuwan hukum diajak untuk menjelajah hukum secara luas yang intinya tidak lain adalah "Searching for Truth" (pencarian kebenaran). Pencarian kebenaran inilah sebenarnya disebutnya sebagai proses pemaknaan terhadap hukum, dan ini pula merupakan kesadaran visioner, bahwa tugas ilmuwan adalah mencerahkan masyarakat, sehingga dunia pendidikan memberikan kontribusi dan tidak melakukan pemborosan apalagi pengkhianatan. Untuk melihat lebih jelas persoalan di atas, Satjipto Rahardjo memberikan gambaran tentang kajian dua domain ilmu hukum yang berbeda itu seperti ragaan berikut.

Mendasarkan dari pemikiran Satjipto Rahardjo, maka implikasinya ke dalam ilmu hukum adalah sebagai berikut. Pertama, sikap ilmuwan yan harus senantiasa menyikapi ilmu sebagai sesuatu yang terus berubah, bergerak

27 Satjipto Rahardjo, 2000, Mengajarkan Keteraturan Menemukan Ketidak Teraturan (Teaching Order Finding Disorder), Pidato Emeritus FH UNDIP dan mengalir, demikian pula ilmu hukum (the changing frontier of science), dan ini pula yang disebutnya dengan "the state of the arts in science".

SEBENAR ILMU
Science
Genuine Science: What is a law?
about law
Credo: in search for the truth, the truth
Pencarian, Pembebasan, dan
Pencerahan
Indevinitive: batas-batasnya kabur
Orientasi: Komunitas dunia ilmu
Kesadaran: Pencarian kebenaran
ILMU PRAKTIS
Itmu Hukum Positif; what should be
considers as law ?
a. praktis
b. ketrampilan/skill hukum positif
c. profesional study; lawyers law-law for
the lawyers
Credo: Rules and logic
Concern: What to do? How to do?
Mempertahankan hukum positif final
definitif

Kedua, hukum sebagai wilayah terbuka harus memiliki pandangan holistik dalam ilmu hukum yang memberikan kesadaran visioner bahwa sesuatu dalam tatanan tertentu memiliki bagian yang saling berkaitan baik dengan bagian lainnya atau dengan keseluruhannya; ketiga, ilmuwan hukum mesti menjelajah hukum secara luas yang memberikan pemaknaan terhadap hukum sebagai pencarian kebenaran (searching for truth); dan keempat, semangat pencarian, pembebasan dan pencerahan yang merupakan hakikat pemikiran hukum progresif melihat transformasi hukum mengalami "bifurcation" (pencabangan) dari corak hukum yang bersifat formalism, rasional dan bertumpu pada prosedur (formal justic atau legal justice), ke arah pemikiran yang lebih mengedepankan "substansial justice". ${ }^{28}$

28 Lihat tentang pemikiran hukum progresif ini pada Satjipto Rahardjo, "Hukum Progresif: Hukum yang Membebaskan", Jurnal Hukum Progresif Vol. 1 No. 1 April 2005 PDIH Undip Semarang, hlm. 1-24; Umbu Lily Pekuweli, "Memaknai Hukum dalam Keutuhan Ontologinya (Suatu Kajian Historis)", Jurnal Hukum Pro Justitia Vol 26 No. 1 Januari 2008 FH Unpar Bandung, hlm. 79-90; Al. Wisnubroto, "Pendekatan Hukum Progresif dalam Mengantisipasi Perkembangan Kejahatan Berbasis 
Berbicara tentang pembinaan lembaga dan pranata hukum agar sesuai yang diharapkan hakikatnya terkait dengan masalah sistem hukum, dan pembangunan sistem hukum sangat terkait dan bahkan harus dimulai dari pembangunan ilmu hukumnya. Ibarat hukum sebagai produk teknologi agar bisa beroperasi dengan baik diperlukan pemahaman ilmunya yang baik pula.

Kita menyadari bahwa pendidikan ilmu hukum yang diselenggarakan di sebagaian besar Fakultas Hukum umumnya masih terfokus pada tradisi transfer of knowledge tentang hukum dan pelatihan ketrampilan (skill) dalam menjalankan hukum saja (practical science/mekanis-prosedural), dan belum merupakan ilmu yang berburu kebenaran dan keadilan sejati. Ilmu yang mengandung muatan nilainilai ( $\mathrm{va}$ lues), pengetahuan (knowledge) dan ketrampilan (skill) secara proporsional.

Berdasarkan pemikiran tentang Consilience dari Edward O. Wilson, maka ilmu-ilmu itu mesti menyatu dalam satu kesinambungan. Pada waktu kita berbicara tentang hukum sebagai tata perilaku manusia, ${ }^{29}$ maka hal tersebut di dasarkan pada kaitan antara ilmu hukum dan ilmu masyarakatnya. Indonesia sebagai suatu "peculiar form of social life" maka Pancasila muncul. Dengan paradigma consilience maka hukum mesti harus mendasarkan pada basic value masyarakat yang tidak lain adalah Pancasila.

Gerald Turkel mengemukakan bahwa "law is constructed by people and is a condition of their lives. The law should express a common morality that is based on a deeply held consensus of what is right and wrong". ${ }^{30}$ Dalam konteks Indonesia Pancasila adalah pandangan hidup (way of life), moralitas dan sistem filsafat bangsa Indonesia. Oleh karenanya Pancasila mesti sebagai paradigma ilmu hukum dan hukum di Indonesia.

Teknologi”, Jurnal Hukum Progresif Vol. 1 No. 2 Oktober 2005 PDIH Undip Semarang, hlm. 97-122.

29 Hans Kelsen, 2006, Terjemahan dari Pure Theory of Law, Bandung: Nusamedia, hlm. 34.

30 Gerald Turkel, 1996, Law And Society: Critical Approaches, University of Delaware, USA, hlm. 7-11.
Pemahaman holistik itu melihat hukum sebagai khasanah normatif merupakan bangunan yang tertanam dan berakar pada masyarakatnya (normatieve maatschappij wetenschap). Dengan demikian ilmu hukum dan studi hukum di Indonesia perlu menanamkan atau mengakarkan diri pada masyarakatnya. Pada saat itulah Pancasila akan muncul sebagai realitas dan karena itu, sebagai suatu disiplin sains, ilmu hukum memerlukan pembicaraan dan pembahasan yang mendalam tentang tempat Pancasila dalam ilmu hukum.

Untuk mencapai derajat keadilan, maka langkah strategis yang perlu ditempuh adalah dengan menanamkan nilai-nilai Pancasila sebagai dasar pengembangan ilmu hukum Indonesia. Mengembangkan core philosophy Pancasila sebagai suatu filsafat bangsa Indonesia yang revitalisasi dan reaktualisasi nilai-nilainya ke dalam hukum merupakan suatu imperative yuridis.

Peran Pancasila sebagai Penguatan Struktur Hukum, Kultur Hukum dan Substansi Hukum Nasional.

Persoalan pembangunan hukum nasional di era globalisasi harus diletakkan pada konsep penguatan sistem hukum yang meliputi aspek struktural, kultural dan subsatantif. Elemen struktur (structure) sistem hukum oleh Friedmann dirumuskan sebagai berikut.

The structure of a legal system consists of elements of this kind: the number and size of courts, their yurisdiction (that is, what kind of cases they hear. And how and why), and modes of appeal from one court to another. Structure also means how the legislature is organized, how many members sit on the Federal Trade Commission, what a president can (legal) do or not do, what procedures the police department follows, and so on. ${ }^{31}$

Mengacu pada rumusan di atas, maka pengadilan beserta organisasiya dan Dewan Perwakilan Rakyat merupakan elemen struktur hukum. Demikian juga lembaga eksekutif dan

31 Gayus Lumbuun, 2007, Aktualisasi Struktur Hukum Dalam Sistem Hukum Pancasila, Makalah Fak. Hukum UGM, Yogyakarta 
yudikatif. Mahkamah Agung (MA) dan lembaga peradilan lainnya, Mahkamah Konstitusi (MK), Komisi Yudisuial (KY) merupakan aspek struktur hukum di Indonesia. Demikian pula lembaga eksekutif sesungguhnya merupakan bagian dari struktur hukum, karena lembaga-lembaga tersebut seperti Kepolisian Republik Indonesia, Kejaksaan Republik Indonesia merupakan elemen penting dalam sistem hukum.

Aktualisasi nilai-nilai Pancasila dalam struktur hukum lebih menekankan pada spirit, motivasi, ajaran bagi para pemegang amanah dalam rangka mewujudkan negara hukum di Indonesia yang diabdikan untuk sebesar-besar kemakmuran rakyat. ${ }^{32}$

Dari perspektif nilai-nilai Pancasila, reformasi ketatalaksanaan (birokrasi) dimaksudkan agar melahirkan suatu birokrasi yang berorientasi pada kepentingan akyat, birokrasi yang peka terhadap kontrol sosial, birokrasi yang menjaga persatuan dan kesatuan nasional, birokrasi yang menjunjung tinggi profesionalisme dan kualitas pelayanan kepada masyarakat. Reformasi birokrasi juga mengarah pada konsep pemerintahan yang bersih dan berwibawa, yang menjunjung tinggi dan mendasarkan pada "Asas-asas Umum Pemerintahan Yang Baik".

Ada tiga prinsip penting untuk menjamin terlaksanannya "clean and good governance". Pertama, prinsip partisipasi publik penyelenggaraan administrasi pemerintahan (public participation); kedua, akuntabiltas pelaksanaan administrasi pemerintahan, dan mekanisme kontrol menyangkut putusan kepentingan publik; dan ketiga, prinsip transparansi (transparency) atau proses pengambilan keputusan yang

32 Lihat penjelasan negara hukum ini pada Marjanne Termorshuizen-Art, "The Concept Rule of Law", Jurnal Hukum Jentera Edisi 3 Tahun II November 2004, hlm. 77-120; B. Arief Sidharta, "Kajian Kefilsafatan tentang Negara Hukum", Jurnal Hukum Jentera Edisi 3 Tahun II November 2004, hlm. 121-129. Bandingkan pemahaman negara hukum ini dengan pemikiran Soepomo pada Daniel Hutagalung, "Menapaki Jejak Pemikiran Soepomo tentang Negara Indonesia", Jurnal Hukum Jentera Edisi 10 Tahun III Oktober 2005, hlm. 114-117; Tristam Pascal Moeliono, "Negara Hukum Indonesia: Antara Gagasan dan Kenyataan", Jurnal Hukum Pro Justitia Vol. 26 No. 3 Juli 2008 FH Unpar Bandung, hlm. 249-262. rasional, diabdikan untuk dan terbuka kepada masyarakat.

Terkait dengan penguatan kultur hukum, Friedman mengungkapkan bahwa "legal culture refers, as we have said, to ideas, attitudes, expectations and opinions about law, held by people in some given society". Dalam hal ini kesamaan cita, pikiran, sikap, harapan dan pandangan tentang hukum manusia Indonesia yang dibangun di atas pondasi Pancasila sebagai falsafah dan dasar negara.

Kultur hukum Pancasila yang hendak dibangun setidaknya memiliki cara pikir, cara pandang, sikap dan perilaku yang mengakui, menerima dan menghormati agama dan kepercayaan yang berbeda-beda, serta kebebasan untuk memilih, memeluk dan melaksanakan ibadahnya; mengakui, menghormati, menjunjung tinggi dan menjaga hak-hak asasi manusia; mengakui dan menghormati perbedaan sebagai kesatuan untuk dibangun dan disejahterakan bersama; menjunjung tinggi prinsip kedaulatan rakyat dan demokrasi, dengan mengutamakan musyawarah dalam proses pengambilan keputusan; dan menjadikan keadilan sosial sebagai cita-cita bersama.

Di bidang hukum, permasalahan hukum kontemporer saat ini digambarkan dalam rencana pembangunan 2004-2009 mencakup seluruh elemen sistem hukum, antara lain terjadinya degradasi budaya hukum di kalangan masyarakat. Pancasila adalah peradaban Bangsa Indonesia, maka kultur hukum Pancasila harus ditumbuhkan, harus ada dan kuat, sehingga keberadaan peradaban itu terjamin khususnya dalam kehidupan hukum.

Wacana Pancasila akan selalu hidup atau tidak pernah mati selama Indonesia sebagai sebuah bangsa masih eksis. Dikatakan Budayawan Mochtar Pobottinggi bahwa

"Tiap sila dalam Pancasila mustahil di bekukan, apalagi perpaduan dan koherensi dari kelima-limanya. Sebagai kesatuan yang utuh, ia menantang manusiamanusia Indonesia kini dan nanti untuk terus menyusun dan melaksanakan rangkaian demi rangkaian agenda politik yang subtil, cerdas, dan prograsif. Tak satupun kontrak politik lainnya sejak proklamasi 
kemerdekaan kita hingga kini yang bisa disesejajarkan dengan Pancasila. ${ }^{33}$

Cara efektif untuk membangun dan mewujudkan kultur hukum adalah melalui pendidikan yaitu dengan penguasaan dan pengembangan ilmu hukum dengan mengaktualisasikan pemahaman dan pemaknaan Pancasila. Penguatan kultur hukum Pancasila dalam kegiatan penegakkan hukum antara lain dengan tidak melakukan diskriminatif, bersikap taat dan adil, menjunjung tinggi etika profesi dan moral. Terkait dengan substansi hukum, Pancasila berperan sebagai sumber dan kaidah pe-nuntun hukum, dalam hal ini Pancasila menjadi cita hukum (rechtsidee) yang harus dijadikan dasar dan tujuan setiap hukum di Indonesia. ${ }^{34}$

Oleh sebab itu setiap hukum yang lahir di Indonesia harus berdasar pada Pancasila dengan memuat konsistensi isi mulai dari yang paling atas sampai yang paling rendah hirakinya. Hukum-hukum di Indonesia juga harus ditujukan untuk mencapai tujuan negara sebagaimana tertuang dalam Pembukaan UUD 1945. Sehingga politik hukum haruslah dipandang sebagai upaya menjadikan hukum sebagai alat pencapaian tujuan negara dari waktu kewaktu sesuai dengan tahaptahap perkembangan masyarakat.

Pancasila sebagai "Screening Board" terhadap Nilai-Nilai Universal dan Paradigma Membangun Hukum Nasional

Globalisasi dengan segala parameternya tidak hanya merupakan fenomena pasar atau transaksi finansial global semata, tatapi secara global telah menyebar luaskan paradigma politik, pola budaya dan pemikiran sosial yang mengandung standarisasi dalam berbagai hal. Globalisasi telah lebih jauh berpengaruh terhadap kedaaulatan negara dan struktur politik, ekonomi, serta sosial yang ada.

Berbagai dampak globalisasi akan muncul baik di sektor politik, ekonomi maupun sosial

33 Mochtar Pabottinggi, "Mengapa Tetp Pancasila", Majalah Tempo, Edisi 17/XXXV/19-25 2006

34 Moh. Mahfud MD, 2007, Penuangan Pancasila Dalam Peraturan Perundang-undangan, Seminar Nasional, UII Yogyakarta, hlm. 2. antara lain mendorong kekuasaan melewati perbatasan nasional ke arah regional dan domain global; menarik kekuasaan dari pemerintah kearah peran masyarakat sipil (non state actors); internasionalisasi konflik yang seringkali bersifat multidemensional serta dinamik; bermunculan permasalahan yang berkaitan dengan HAM, keamanan, kejahatan, demokrasi, masalah lingkungan dan lain sebagainya; dan nilai-nilai global, kebiasaan-kebiasaan dan konvensi internasional dalam pembangunan hukum nasional menjadi bagian yang harus diperhatikan.

Konsep "ketahanan hukum nasional" harus tetap diperhatikan untuk tetap menjadikan hukum nasional sebagai upaya melindungi kepentingan nasional. Upaya untuk "membentuk" suatu mindset kebersamaan dan kerjasama sinergis bangsa Indonesia dan membangun rasa kekeluargaan (brotherhood, bukan kinship), perasaan saling memiliki (shared intrerest dan common property $)^{35}$ perlu dikembangkan, baik yang berada di tingkat keluarga, ketetanggaan, ${ }^{36}$ masyarakat luas hingga ke tingkat negara. Demikian pula halnya, orientasi mutualisme dan kerjasama sinergis sebagai jiwa dalam UUD 1945 itu harus menjadi titik-tolak dan landasan bagi penyusunan program-program pembangunan nasional secara luas.

Apabila dikaitkan dengan proses pembentukan tingkah laku manusia, maka proses globalisasi membawa tiga kemungkinan, yaitu terjadi peningkatan interaksi, interdependensi dan saling pengaruh; terbuka pilihan pengembangan diri yang memerlukan penyesuaian prioritas tindakan secara terus menerus sesuai dengan keinginan dan kebutuhannya; dan se-

35 Lihat tulisan M.F.H. Swasono, Generasi Muda Minangkabau di Jakarta: Masalah Identitas Sukubangsa. Skripsi Sarjana. Jakarta: Fakultas Sastra Universitas Indonesia, 1974.

36 Di tingkat keluarga dan ketetanggaan, prinsip kebersamaan dapat menggalang pertolongan dan perlindungan, dalam menghadapi tantangan kehidupan yang berat, tidak saja di bidang ekonomi tetapi juga di bidang kesehatan, pekerjaan, dan lain-lain. Perawatan sosial, kepedulian dan perlindungan sosial yang menenteramkan batin dan mendorong kesehatan mental yang baik dapat digalang dan dikemas dalam landasan kebersamaan ini bagi warga masyarakat yang mengalami penderitaan. 
cara psikologis terjadi perubahan kognitif, perubahan kebutuhan, yang kemudian membawa pembentukan nilai (pemberian skala prioritas) terhadap hal-hal yang dianggap bermakna dalam hidupnya. Era globalisasi yang semakin terasa denyutnya memerlukan penampilan manusia Indonesia yang berkualitas tinggi, sehingga dapat mengikuti perkembangan dunia, yang selanjutnya akan dapat menghasilkan peran serta aktif di berbagai bidang (pertanian, perdagangan, perindustrian, teknologi, kesehatan, pendidikan, hukum, dan sebagainya).

Elemen "psychological" yang terdiri atas "national will and morale, national character and degree of national integration", dalam mendayagunakan konsep ketahanan hukum nasional ${ }^{37}$ merupakan filter dalam mentransformasikan nilai-nilai global dalam kehidupan nasional. Dalam hal ini Pancasila berperan sebagai elemen karakter psikologis bangsa (national character).

Pendekatan "transformasionalis" adalah paling tepat dan bukan menerima bulat-bulat globalisasi atau menolaknya. Untuk itu ideologi Pancasila jelas akan sangat dibutuhkan untuk menentukan posisi dan arah kebijakan pembangunannya. Dalam hal ini Pancasila akan menjadi rujukan "political willand moral" dalam menghadapi dan usaha mengatasi kondisi nasional dan global. Pancasila adalah ideologi nasional bangsa Indonesia. Dasar Negara Republik Indonesia. Falsafah bangsa: welthanschaung. Pandangan hidup bangsa (way of life). Jati diri bangsa. Perekat dan pemersatu bangsa.

Muladi menyebutnya sebagai "margin of appreciation". Margin of appreciation diartikan sebagai batas pembenaran dalam kehidupan berbangsa. ${ }^{38}$ Pemikiran ini dipengaruhi oleh proses globalisasi yang sangat kompleks akibat kemajuan teknologi informatika, transportasi dan komunikasi modern yang bisa berdampak positif atau negatif. Dalam kerangka ini prinsipprinsip keilmuan dan karakter ilmu hukum harus mendayagunakan Pancasila sebagai para-

37 Muladi, op.cit. hlm. 7

38 Ibid, hlm. 5. digma dan "Margin Of Appreciation" atau bahkan "screening board" yang akan berimplikasi dalam pembentukan teori hukum dan praktik hukum di Indonesia adalah sebagai berikut. Pertama, tidak boleh bertentangan dengan prinsip prinsip ketuhanan Yang Maha Esa yang menghormati ketertiban hidup beragama, rasa keagamaan dan melihat agama sebagai kepentingan hukum yang besar; kedua, menghormati nilai nilai Hak Asasi Manusia (HAM) baik hak hak sipil dan politik maupun hak hak ekonomi, sosial dan budaya serta Kam; ketiga, harus menghargai "Civic Nasionalism" yang mengapresiasikan pluralisme; keempat, harus menghargai Indeks atau "Core values of Democracy"; dan kelima, harus menempatkan "Legal Justice"dalam kerangka keadilan sosial. Dengan menempatkan Pancasila sebagai paradigma ilmu (ilmu hukum), maka upaya membangun bangsa melalui ilmu menjadi jelas arahnya, yakni diabdikan untuk kepentingan nasional dan kemaslahatan seluruh umat dalam naungan ridha Tuhan Yang Maha Esa.

Paradigma pendidikan hukum di Indonesia yang menggunakan tradisi Civil Law dari Eropa Kontinental yang cenderung mengajarkan positivisasi hukum yang memberlakukan hukum sebagai kaidah-kaidah positif, bersifat yuridis normatif disertai penalaran formal deduktif. Pendekatan semacam ini sangat bermanfaat untuk menciptakan pembenaran (justification) atau legitimasi, bukan kebenaran (truth) yang bersifat empiris. Dengan sistem pendidikan hukum semacam ini hukum cenderung sebagai alat kekuasaan semata-mata (law as the command of the sovereign).

Perubahan fungsi hukum di masa Kolonial dari "tool of colonial machinery", "tool of authoritarian machinery", positivistik yang jauh dari prinsip-prinsip keadilan menjadi "tool of reform and democratization machinery". Dalam perspektif yang seperti ini ilmu-ilmu sosial didayagunakan untuk bermanfaat mencegah persoalan-persoalan hukum dan ketertiban sosial dalam kerangka perlindungan masyarakat. ${ }^{39}$

39 Lihat dan bandingkan mengenai berbagai kritik terhadap fungsi hukum ini dalam Syahmin A.K., "Meng- 
Pendidikan hukum dan pengembangan ilmu hukum harus meninggalkan nuansa positivisme, yang melihat hukum semata-mata sebagai "Positive Judgment" penguasa yang menjauhi tradisi empiris. Pengembangan hukum dengan demikian harus dilakukan dengan "double track system" yaitu doctrinal dan nondoktrinal. Secarasingkat dapat dikatakan bahwa hukum harus didekati atas dasar karakteristik kepribadian sebagai "Sociological or Functional Jurisprudence"

Pendidikan ilmu hukum yang diselenggarakan oleh Fakultas-Fakultas Hukum di negeri ini umumnya masih terfokus pada tradisi "transfer of knowledge" tentang hukum dan pelatihan ketrampilan (skills) dalam menjalankan hukum saja. Ilmu hukum yang dipelajari dan diajarkan masih sebatas ilmu praktis (practical science), yaitu ilmu hukum untuk melayani kebutuhan profesi, dan belum merupakan ilmu yang berburu kebenaran dan keadilan sejati (searching for truth and justice).

Tradisi pendidikan hukum "bermasalah" di Indonesia hingga saat ini sebenarnya tidak lepas dari pengaruh kuat dari dua tradisi pendidikan hukum yang dominan, yaitu pertama pendidikan hukum Eropa Kontinental yang cenderung berorientasi kepada penguasaan perundang-undangan serta doktrin-doktri hukum; dan kedua pengaruh kuat dari tradisi pendidikan hukum Amerika yang berbasis komersial dan berorientasi pada kebutuhan pasar (klien), sebagaimana sering disebut tradisi Cravathism. ${ }^{40}$

Pendidikan ilmu hukum bukanlah sekedar alih pengetahuan (transfer of knowledge) ten-

kritik Pandangan Mochtar Kusumaatmadja yang Mengintrodusir "Hukum sebagai Sarana Pembanguan masyarakat di Indonesia" Jurnal Hukum Progresif Vol. 1 No. 2 Oktober 2005, hlm. 31-56; lihat juga persoalan perkembangan hukum pada Dadang Trisasongko, "Pembaruan Hukum di Jaman yang Sedang Berubah", Jurnal Hukum Jentera Edisi 3 Tahun II November 2004, hlm. 51-57; Soetandyo Wignjosoebroto, “Dinamika Tata Hukum dan Pemerintahan Era Kekuasaan Kolonial di Indonesia”, Jurnal Hukum Jentera Edisi 3 Tahun II November 2004, hlm. 129-142.

40 Laporan Hasil Penelitian, 2006, Pokok-Pokok Hasil Penelitian tentang Nilai-Nilai Pancasila Sebagai Nilai Dasar Pengembangan Ilmu Hukum Indonesia, Tim Peneliti Fakultas Hukum UGM dan Fakultas Hukum Universitas Pancasila Jakarta tang hukum, dan bukan pula sekedar pelatihan ketrampilan (skills) menjalankan hukum, melainkan termasuk di dalamnya pendidikan tentang nilainilai (values) yang menjadi basis sistem hukum nasional yang hendak dibangun. Dan bagi bangsa Indonesia nilai-nilai (values) tersebut adalah nilai-nilai Pancasila. Langkah strategis yang perlu ditempuh adalah dengan menanamkan nilai-nilai Pancasila sebagai dasar pengembangan ilmu hukum.

Memposisikan Pancasila sebagai dasar pengembangan ilmu hukum atau sebagai paradigma ilmu hukum adalah sebuah keniscayaan, dengan paradigm Pancasila pendidikan hukum diselenggarakan melalui keutuhan pemahaman, penggarapan dan penyelenggaraan hukum dalam suatu proses pencapaian keadilan dan kebahagiaan manusia, konstruksi hukum tidak boleh hanya pada tataran rasionalitas, melainkan harus didasarkan, diawali dan dikendalikan oleh hati nurani. Ada dialog dan penghargaan terhadap semua entitas, arah perkembangan, sasaran, dan tujuan pendidikan hukum tidak boleh dibatasi pada pencapaian kepentingan individu, kelompok, partai, atau golongan akan tetapi mencakup keseluruhan dan kesatuan kepentingan manusia dalam posisinya sebagai individu, mahluk sosial, sekaligus sebagai kalifatullah.

Melalui hukum sebagai instrumen pembangunan, maka dalam proses pembuatan hukum (law making proces), proses penegakkan hukum (law enforcement process), dan kesadaran hukum (law awareness process) diharapkan dapat menggunakan Pancasila sebagai filter dalam pelembagaan nilai-nilai universal dan domestik menjadi nilai-nilai yang diakui secara nasional.

Pancasila bagi bangsa Indonesia merupakan Grundnorm atau basic norm, yang menurut Hans Kelsen "basic norm's as the source of validity and as the source of unity of legal systems". ${ }^{41}$ Oleh karena itu Pancasila merupakan sumber nilai bagi adanya sistem hukum. Dengan demikian Pancasila juga merupakan cita hukum

$41 \quad$ Ibid 
(rechts idee) yang dipahami sebagai konstruksi pikir yang mengarahkan hukum pada cita-cita yang diinginkan. ${ }^{42}$

Pancasila, dalam kedudukan sebagai "basic norm dan rechts idee", maka kaitan Pancasila dengan pembinaan lembaga dan pranata hukum adalah sebagai berikut. Pertama, cita hukum (Pancasila) berfungsi sebagai tolok ukur yang bersifat regulative dan konstruktif, tanpa cita hukum maka produk hukum yang dihasilkan akan kehilangan maknannya. Dalam hal ini Pancasila menjadi standar penilaian dalam peraturan perundang-undangan di Indonesia. ${ }^{43}$ Kedua, cita hukum (Pancasila) adalah faktor yang memotivasi dan mempedomani (guiding principle) dalam penyelenggaraan hukum (law making process, law enforcement maupun law awareness); dalam hal ini "moral principles is the foundation of law"'. Ketiga, cita hukum (Pancasila) menentukan masalah, metoda dan penjelasan yang dianggap relevan untuk di telaah sehingga merupakan kunci pembentukan hukum oleh lembaga-lembaga hukum. Keempat, sebagai norma kritik (kaidah evaluasi) dalam menghadapi tantangan kaitannya dengan penegakan hukum, karena ia berfungsi sebagai "margin of appreciation" yaitu batas-batas pembenaran, tolok ukur tentang etika dan moral, kehormatan dan martabat bangsa. Kelima, cita hukum (Pancasila) sebagai bintang pemandu (leitstern) bagi tercapainya cita-cita masyarakat. ${ }^{44}$

Terkait dengan era globalisasi dan reformasi yang hakikatnya adalah perubahan dan kesinambungan yang penuh dengan nuansa ketergantungan antar negara di segala bidang, akan menyadarkan kita pada ketergantungan sistem politik nasional kepada sistem politik global yang pada akhirnya akan berpengaruh pula terhadap sistem hukum yang berlaku. Dalam berbagai pergolakan sistem politik ter-

Sholehuddin, op.cit, hlm. 23.

43 Ibid, hlm. 20.

44 Bandingkan pendapat ini dengan tulisan Bob Sugeng Hadiwinata mengenai penegakan hukum dalam masyarakat sipil. Bob Sugeng Hadiwinata, "Un-civil" dan Problematika Penegakan Hukum di Indoensia", Jurnal Hukum Pro Justitia Vol. 24 No. 3 Juli 2006 FH Unpar Bandung, hl.203-211. sebut, sekalipun mengalami pasang surut dalam penafsiran dan penghayatan, namun apa yang dinamakan ideologi Pancasila dalam bentuknya yang asli selalu "untauchable" dalam perubahan, sehingga tidak ada salahnya dalam reformasi hukum juga harus difikirkan untuk menjadikan Pancasila sebagai "margin of appreciation" baik dalam pengembangan teori-teori hukum maupun dalam praktik hukum yang berlaku yang meliputi proses-proses "law making, law enforcement, and law awareness". ${ }^{45}$

\section{Penutup}

Simpulan

Ada beberapa simpulan yang dapat diberikan berdasarkan pada permasalahan dan pembahasan tersebut di atas. Pertama, strategi pembangunan hukum nasional di tengah arus globalisasi yang multi dimensional harus tetap terkendali dengan memposisikan Pancasila sebagai "margin of appreciation" atau "screening board".

Kedua, pokok-pokok pikiran yang harus menjadi acuhan pembangunan hukum meliputi (a) hukum itu berwatak mengayomi/melindungi segenap bangsa dan tumpah darah Indonesia, berdasarkan persatuan dalam rangka mewujudkan keadilan sosial bagi seluruh rakyat Indonesia; (b) hukum harus mampu mewujudkan keadilan sosial bagi seluruh rakyat Indonesia; (c) hukum berasal dari rakyat dan mempunyai sifat kerakyatan atau dengan kata lain adanya prinsip kedaulatan rakyat; dan (d) hukum berdasarkan nilai Ketuhanan Yang Maha Esa, yang memberikan dasar pengaturan terhadap adanya hukum-hukm Tuhan, disamping memperhatikan nilai-nilai kemanusiaan, nilai-nilai moral, dan budi pekerti yang luhur.

Ketiga, cita hukum (Pancasila) adalah sebagai bintang pemandu (leitstern) bagi tercapainya cita-cita masyarakat dan faktor yang

45 Lihat dan bandingkan perkembangan pengaruh berbagai sistem hukum di Indonesia yang bisa digunakan untuk menilai sampai di manakah sebenarnya Pancasila di gunakan atau memberi pengaruh dalam pengembangan hukum di Indonesia pada tulisannya Hari Purwadi, "Translokasi Hukum di Indonesia: Koeksistensi Beberapa Sistem Hukum", Jurnal Hukum Progresif Vol. 1 No. 1 April 2005 PDIH Undip Semarang, hlm. 69-86 
memotivasi dan mempedomani (guiding principle) dalam penyelenggaraan hukum (law making process, law enforcement maupun l aw awareness).

Keempat, reformasi, hakikatnya adalah perubahan dan kesinambungan, karena itu dalam konteks globalisasi remaking Indonesia, rebirth of a nation itu, untuk tidak meninggalkan fundamental consensus yang telah diletakkan oleh para Pendiri Republik.

Kelima, pendekatan "transformasionalis" adalah paling tepat dan bukan menerima bulatbulat globalisasi atau menolaknya. Untuk itu ideologi Pancasila jelas akan sangat dibutuhkan untuk menentukan posisi dan arah kebijakan pembangunan. Pancasila menjadi rujukan "political will and moral" dalam menghadapi dan usaha mengatasi kondisi nasional dan global.

\section{Saran}

Perlu upaya terus menerus untuk mereaktualisasi nilai-nilai Pancasila dalam segala segi kehidupan nasional antara lain dengan membangun sistem hukum Pancasila, serta komitmen bangsa terhadap pelestarian Pancasila.

\section{Daftar Pustaka}

Adolf dkk. 2007. Globalisasi dan Dampaknya Terhadap Sistem Regulasi Bidang Investasi Dalam Pelaksanaan Otonomi Daerah. Yogyakarta: Genta Press;

AK, Syahmin. "Hukum sebagai Sarana Pembangunan masyarakat di Indonesia". Jurnal Hukum Progresif. Vol 1 No. 2. Oktober 2005. Semarang: FH UNDIP;

Ananda, Suadamara. “Tentang Kaidah”, Jurnal Hukum Pro Justitia. Vol 26. No. 1 Januari 2008. Bandung: FH Unpar;

Anderson, Benedict. 1983. Imagined Communities: Reflection on the Origin and Spread of Nationalism, Wonder: Verso. Mengenai hegemonisme dan predatorisme;

Arinanto, Satya. "Politik Pembangunan Hukum Nasional Dalam Era Pasca Reformasi". Jurnal Konstitusi. Volume 3 Nomor 3. 2006;
Brian Z, Tamanaha. 2006. A General Jurisprudence Of Law And Society. New York: Oxford University Press;

Emirzon, Joni. "Strategi Hukum Dalam Pembangunan Hukum Ekonomi Indonesia di Era Globalisasi". Jurnal Hukum Progresif. Vol. 2 No. 2. 2007. Semarang: FH UNDIP;

Frank Lechner dalam George Ritzer. 2006. The Globalization of Nothing. Yogyakarta: Universitas Atmajaya;

Greenfeld, Leah. 2001. The Spirit of Capitalism: Nationalism and Economic Growth, Cambridge, Mass.: Harvard University Press;

Hadisuprapto, Paulus. "Ilmu Hukum dan Pendekatannya". Jurnal Hukum Progresif. Vol 2 No. 2. Oktober 2005. Semarang: PDIH Undip;

Hadiwinata, Bob Sugeng. "Un-civil" dan Problematika Penegakan Hukum di Indoenesia”. Jurnal Hukum Pro Justitia. Vol. 24 No. 3. Juli 2006. Bandung: FH Unpar;

Hartono, Sunaryati. 1991. Pembinaan Hukum Nasional Dalam Suasanan Globalisasi Masyarakat Dunia. Pidato Pengukuhan Guru Besar. Bandung: UNPAD;

dalam B. Arief Sidharta. 2000. Refleksi Tentang Struktur Ilmu Hukum Sebuah Penelitian Tentang Fondasi Kefilsafatan dan Sifat Keilmuan Ilmu Hukum Sebagai Landasan Pembangunan Ilmu Hukum Nasional Indonesia. Bandung: Mandar Maju;

Kelsen, Hans. 2006. Terjemahan dari Pure Theory of Law. Bandung: Nusamedia;

Koeswahyono, Imam. "Mempertemukan dan Membumikan Pandangan Teoritik dan Praktik: Suatu Upaya Pembaruan Hukum". Jurnal Hukum Jentera. Edisi 10. Tahun 3. Oktober 2005;

Laporan Hasil Penelitian. 2006. Pokok-Pokok Hasil Penelitian tentang Nilai-Nilai Pancasila Sebagai Nilai Dasar Pengembangan Ilmu Hukum Indonesia. Tim Peneliti Fakultas Hukum UGM dan Fakultas Hukum Universitas Pancasila Jakarta;

Lumbuun, Gayus. 2007. Aktualisasi Struktur Hukum Dalam Sistem Hukum Pancasila. Makalah. Yogyakarta: Fak. Hukum UGM;

Lustick, lan S. "The Riddle of Nationalism: The Dialectic of Religion and Nationalism in 
the Middle East". Logos. Vol. One Issue Three. Summer 2002;

MD, Moh Mahfud. 2007. Penuangan Pancasila Dalam Peraturan Perundang-undangan. Seminar Nasional. Yogyakarta: UII;

MFH, Swasono. Generasi Muda Minang-kabau di Jakarta: Masalah Identitas Sukubangsa. Skripsi Sarjana. Jakarta: Fakultas Sastra Universitas Indonesia;

Miyasto. 2007. Bahan Kuliah/Matrikulasi Transformasi Global (Ekonomi). Semarang: PDIH UNDIP;

Moeliono, Tristam Pascal. "Negara Hukum Indonesia: Antara Gagasan dan Kenyataan". Jurnal Hukum Pro Justitia. Vol 26 No. 3. Juli 2008. Bandung: FH Unpar;

Muladi. 2005. "Menggali Kembali Pancasila Sebagai Dasar Pengembangan Ilmu Hukum Indonesia". Jurnal Hukum Progresif. Volume I. Nomor 1. April 2005;

2007. Reformasi Hukum Dalam Kerangka Pembangunan Sistem Hukum Nasional. Jakarta: LEMHAN-NAS;

-..--.-. tt. "Menjamin Kepastian, Ketertiban, Penegakkan dan Perlindungan Hukum Dalam Era Globalisasi”. Makalah;

Pabottinggi, Mochtar. 2006. "Mengapa Tetap Pancasila”. Majalah Tempo, Edisi 17/ XXXV;

Parker, Barbara dalam Ade Maman Suherman. 2005. Aspek Hukum Dalam Ekonomi Global. Ciawi Bogor: Ghalia Indonesia;

Pekuweli, Umbu Lily "Memaknai Hukum dalam Keutuhan Ontologinya (Suatu Kajian Historis)". Jurnal Hukum Pro Justitia. Vol 26 No. 1. Januari 2008. Bandung: FH Unpar Bandung;

Petras, James dan Henry Veltmeyer. 2001. Globalization Unmasked: Imperialism in the 20 th Century. London: Zed Books;

Purwadi, Hari. "Translokasi Hukum di Indonesia: Koeksistensi Beberapa Sistem Hukum". Jurnal Hukum Progresif. Vol. 1 No. 1. April 2005. Semarang: PDIH Undip;

Rahardjo, Satjipto. 2000. Mengajarkan Keteraturan Menemukan Ketidak Teraturan (Teaching Order Finding Disorder). Pidato Emeritus FH UNDIP;

. Hukum Progresif: Hukum yang Membebaskan”. Jurnal Hukum Progresif Vol. 1
No. 1. April 2005. Semarang: PDIH Undip;

........ Pendekatan Holistik terhadap Hukum". Jurnal Hukum Progresif. Vol. 1 No. 2. Oktober 2005. Semarang: PDIH Undip;

2006. Pancasila, Hukum dan Ilmu Hukum. Makalah. Jakarta: Univ. Pancasila;

"Hukum Progresif. "Metode Holistik, Suatu Revolusi Epistemologis". Jurnal Hukum Progresif. Vol. 2 No. 2. Oktober 2006. Semarang: PDIH Undip;

Swasono, S E. 2003. "Pluralisme, Mutualisme dan Semangat Bersatu: Mempertanyakan Jatidiri Bangsa", makalah diajukan pada Dies Natalis ke-57 Fakultas IImu Budaya UGM, Yogyakarta 25 Februari;

Salman, Otje dan Anton F Susanto. 2004. Teori Hukum (Mengingat, Mengumpulkan dan Membuka Kembali). Bandung: Refika Aditama;

Samekto, FX Adji. "Kajian Hukum: Antara Studi Normatif dan Keilmuan". Jurnal Hukum Progresif Vol 2 No. 2. Oktober 2005. Semarang: PDIH Undip;

-.-.-.. "Kajian Studi Hukum Kritis: Implikasi Yuridis "Ketidak-Ilmiahan" Pengetahuan Tradisional dalam Pengelolaan Keanekaragaman Hayati”. Jurnal Hu-kum Pro Justitia. Tahun 13. No. 1. Januari 2005. Bandung: FH Unpar;

Sholehuddin. 2004. Sistem Sanksi Dalam Hukum Pidana, Ide Dasar Double Track System \& Implementasinya. Jakarta: Raja Grafindo Persada;

Sidharta, B Arief. "Kajian Kefilsafatan tentang Negara Hukum". Jurnal Hukum Jentera. Edisi 3 Tahun 2. November 2004;

Soepomo pada Daniel Hutagalung. "Menapaki Jejak Pemikiran Soepomo tentang $\mathrm{Ne}$ gara Indonesia". Jurnal Hukum Jentera. Edisi 10 Tahun 3. Oktober 2005;

Termorshuizen Art, Marjanne. "The Concept Rule of Law". Jurnal Hukum Jentera. Edisi 3 Tahun 2. November 2004;

Trisasongko, Dadang. "Pembaruan Hukum di Jaman yang Sedang Berubah". Jurnal Hukum Jentera Edisi 3 Tahun II November 2004;

Turkel, Gerald. 1996. Law And Society: Critical Approaches. USA: University of Delaware; 
166 Jurnal Dinamika Hukum

Vol. 11 Edisi Khusus Februari 2011

Wignjosoebroto, Soetandyo. "Dinamika Tata Hukum dan Pemerintahan Era Kekuasaan Kolonial di Indonesia". Jurnal Hukum Jentera Edisi 3 Tahun II November 2004;

Wisnubroto, Al. “Pendekatan Hukum Progresif dalam Mengantisipasi Perkembangan Kejahatan Berbasis Teknologi”. Jurnal Hukum Progresif. Vol. 1 No. 2. Oktober 2005. Semarang: PDIH Undip;

Yara, Muchyar. "Teori Hukum (Suatu Tinjauan Singkat tentang Posisi, Sejarah Perkembangan dan Ruang Lingkupnya". Jurnal Hukum dan Pembangunan. No. 1-3 Tahun 28 Januari-Juni. 1998. Jakarta: FH UI. 